\title{
INVENTORY OF MOSQUITOES (DIPTERA: CULICIDAE) IN CONSERVATION UNITS IN BRAZILIAN TROPICAL DRY FORESTS
}

Cleandson Ferreira SANTOS(1), Alex Chavier SILVA(1), Raquel Andrade RODRIGUES(1), Jamilli Sanndy Ramos de JESUS(1) \& Magno Augusto Zazá BORGES(1)

\begin{abstract}
SUMMARY
In Brazil, most studies of the Culicidae family are concentrated in rainforest regions. As such, there is a lack of knowledge regarding the diversity of Culicidae in regions with different climatic and vegetational characteristics. The aim of this study was to compile an inventory of Culicidae in protected areas of the semi-arid region of the state of Minas Gerais, Brazil, in order to better understand the diversity of the family within this region. The study was conducted across four protected areas in the northern region of the state, in tropical dry forest (TDF) fragments. Sampling methods included Shannon trap and CDC light trap, as well as active collection. A total of 11,219 mosquito specimens were collected between August 2008 and July 2012, belonging to 11 genera and 45 species; 15 new records for the state of Minas Gerais were registered, as well as 26 new records for semi-arid regions within the state. The high number of new Culicidae records in this region demonstrates the importance of inventory studies for increasing the knowledge of culicid biodiversity in Minas Gerais, and in particular within semi-arid regions of the state.
\end{abstract}

KEYWORDS: Culicidae; Tropical dry forest (TDF); Conservation unit; Semi-arid; Minas Gerais.

\section{INTRODUCTION}

Mosquitoes (Diptera: Culicidae) are a group of insects that in their early stages develop in a variety of aquatic habitats, including permanent (i.e. rivers and lakes) and transient; transient habitats can include any receptacle that accumulates water, such as hollow trees, bromeliad tanks, fallen plant material, and even animal tracks ${ }^{21}$.

Studies of Culicidae diversity in Brazil were mainly focused on rainforests in the southeastern and southern regions of the country, which coincide with the location of major national research centers. The Amazon rainforest is another important, well-studied region, primarily because of its significance for the transmission of several diseases, such as malaria and wild-type yellow fever ${ }^{7}$. However, the authors remain unsure of the diversity of mosquitoes in Brazilian regions with different climatic characteristics and forms of vegetation.

Despite the high diversity of plant and animal species in other biomes, such as the Cerrado (Savanna) and Caatinga (Semi-arid forest), there are very few studies of Culicidae diversity in these areas, and in particular, few in the transition zones between these biomes in northern Minas Gerais (MG). This region is primarily tropical dry forest (TDF), characterized by deciduous forest vegetation and a semi-arid climate, due to low humidity and low rainfall.

The last major survey of Culicidae in Minas Gerais was conducted in 1962 by MACIEL ${ }^{16}$. The author compiled his own data with data from literature, as well as from the former Department of Rural Endemic Diseases. With this, he created a list of the Culicidae in Minas Gerais and the municipalities where they were found, as well as the coordinates of the collection sites. Overall, 119 species of Culicidae were reported as occurring in 168 municipalities. The upper-middle area of the São Francisco region appears in this report due to a study in 1960 by ANDRADE \& LEAL ${ }^{1}$ on Anopheles in the São Francisco river, which contains two surveys done in the city of Manga in 1947 and 1954. Thereafter, the only published work in northern Minas Gerais was by GAMA et al. ${ }^{13}$, in which the authors present a list of Anophelines collected in the municipality of Varzelândia.

The present study aims to conduct an inventory of the Culicid fauna in conservation units within a semi-arid region of the state of Minas Gerais, Brazil, in order to better understand the diversity of Culicidae in this region.

\section{MATERIALS AND METHODS}

Samples were collected within four conservation units administered by the State Forestry Institute (Instituto Estadual de Florestas - IEF). These areas are in the northern region of Minas Gerais, in the mid-São Francisco Valley, and are as follows: (1) the Mata Seca State Park MSSP (Parque Estadual da Mata Seca - PEMS) (1448'36"S - 435'12"), located in the municipality of Manga; (2) the Lagoa do Cajueiro State 
SANTOS, C.F.; SILVA, A.C.; RODRIGUES, R.A.; JESUS, J.S.R. \& BORGES, M.A.Z. - Inventory of mosquitoes (Diptera: Culicidae) in conservation units in Brazilian tropical dry forests. Rev. Inst. Med. Trop. Sao Paulo, 57(3): 227-32, 2015.

Park - LCSP (Parque Estadual Lagoa do Cajueiro - PELC) (1455'08'S - 43 $56^{\prime} 23^{\prime \prime} \mathrm{W}$ ) and (3) the Jaíba Biological Reserve - JBR (Reserva Biológica de Jaíba) (15³'57.81’'S - 4345’45.03”W), both located in the municipality of Matias Cardoso; and (4) the Serra Azul Biological Reserve - SABR (Reserva Biológica de Serra Azul) (15¹1'32.20”S $43^{\circ} 54^{\prime} 41.1^{\prime \prime} \mathrm{W}$ ), located in the municipality of Jaíba (Fig. 1).

As the study areas are located within a Caatinga-Cerrado transition zone, they contain fragments of tropical dry forest (TDF). These formations are broadly defined as having a vegetation type typically dominated by deciduous trees (at least $50 \%$ deciduousness during the dry season), with an average annual temperature $\geq 25^{\circ} \mathrm{C}$, total annual precipitation between 700 and 2,000 mm, and three or more dry months per year (precipitation $<100 \mathrm{~mm} / \mathrm{month}^{22}$ ). According to the Köppen classification, regions with TDFs have a seasonal tropical climate (Aw) with an average annual temperature of $24.4^{\circ} \mathrm{C}$ and an average annual precipitation of $871 \mathrm{~mm}^{2}$.

The Culicidae collections were carried out in 20 x $50 \mathrm{~m}$ plots, located within tropical dry forest fragments during the dry and rainy seasons between August 2008 and July 2012, on a total of 18 nights and across 504 hours of collections in the dry seasons, with the same sampling effort taking place in the wet seasons during the study period. Night trapping utilized two sampling methods, both beginning at dusk: one Shannon-type light trap exposed for a period of two hours and two CDC light traps exposed for a period of 12 hours per plot. A third sampling method consisted of "active collections" used to sample mosquitoes with daytime activity, and was performed once at each sample point for 45 minutes. Briefly, active collections consisted of using a manual vacuum to collect all mosquitoes landing on researcher's bodies prior to the attempted blood meal. Transportation and mounting techniques for mosquitoes were based on previous reports by FORATTINI ${ }^{10}$ and CONSOLI \& OLIVEIRA ${ }^{6}$. Specimens were taxonomically identified and incorporated into the entomological collection of the Laboratory of Ecology and Biological Control of Insects (Laboratório de Ecologia e Controle Biológico de Insetos - LECBI) at Montes Claros State University (Universidade Estadual de Montes Claros - Unimontes). Species identification was carried out using dichotomous keys by CONSOLI \& OLIVEIRA $^{6}$, FARAN ${ }^{9}$, FORATTINI $^{10}$ and LANE $^{15}$.

\section{RESULTS}

During the study period, a total of 11,219 mosquitoes were collected (11 genera and 45 species). There were 15 new records for Minas Gerais overall, and 26 new records for the semi-arid region of Minas Gerais (Table 1).

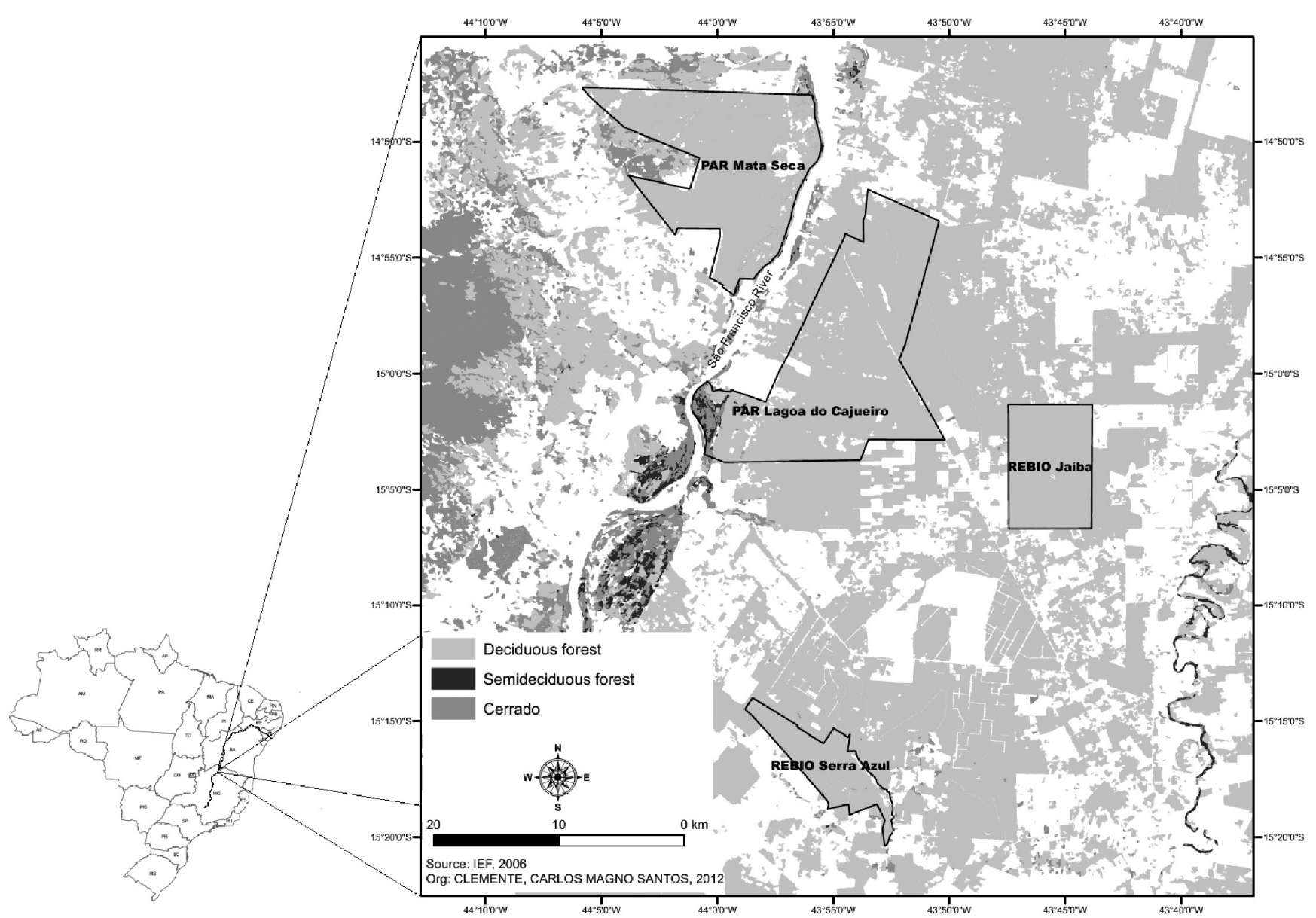

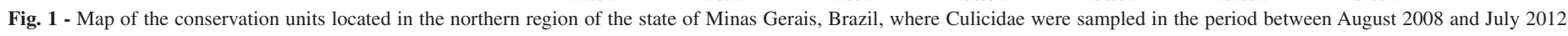
$(215 \times 279 \mathrm{~mm} ; 300 \times 300 \mathrm{DPI})$ 


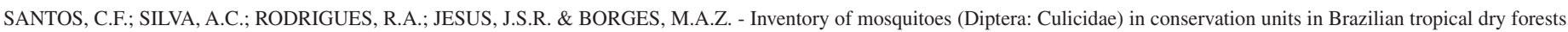
Rev. Inst. Med. Trop. Sao Paulo, 57(3): 227-32, 2015.

Table 1

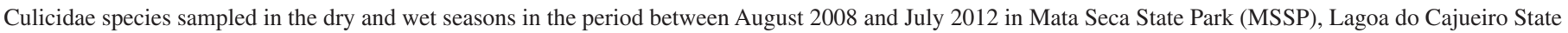
Park (LCSP), Jaiba Biological Reserve (JBR) and Serra Azul Biological Reserve (SABR), in the northern region of the state of Minas Gerais, Brazil

\begin{tabular}{|c|c|c|c|c|c|c|c|c|c|}
\hline \multirow{2}{*}{ SPECIES } & \multicolumn{2}{|c|}{ MSSP } & \multicolumn{2}{|c|}{ LCSP } & \multicolumn{2}{|c|}{ JBR } & \multicolumn{2}{|c|}{ SABR } & \multirow{2}{*}{ Total } \\
\hline & Dry & Wet & Dry & Wet & Dry & Wet & Dry & Wet & \\
\hline \multicolumn{10}{|l|}{ Anophelinae } \\
\hline Anopheles (Nys.) albitarsis Lynch Arribalzaga, 1878 & 19 & 4 & 17 & 9 & 0 & 1 & 0 & 0 & 50 \\
\hline An. (Nys.) argyritarsis Robineau-Desvoidy, 1827 & 23 & 37 & 79 & 13 & 0 & 1 & 0 & 0 & 153 \\
\hline An. (Nys.) braziliensis (Chagas, 1907) & 0 & 2 & 0 & 1 & 0 & 0 & 0 & 0 & 3 \\
\hline An. (Nys.) darlingi Root, 1926 & 53 & 76 & 8 & 16 & 0 & 0 & 0 & 0 & 153 \\
\hline An. (Nys.) deaneorum Rosa-Freitas, $1989+$ & 0 & 0 & 4 & 2 & 0 & 0 & 0 & 0 & 6 \\
\hline An. (Nys.) evansae (Brethes, 1926) + & 0 & 0 & 0 & 1 & 0 & 0 & 0 & 1 & 2 \\
\hline An. (Nys.) triannulatus triannulatus (Neiva \& Pinto, 1922) & 33 & 27 & 2 & 3 & 0 & 0 & 0 & 0 & 65 \\
\hline An. (Nys.) Albimanus section/Oswaldoi Subgroup & 4 & 5 & 0 & 1 & 2 & 0 & 0 & 0 & 12 \\
\hline
\end{tabular}

Culicinae

Tribe Aedomyiini

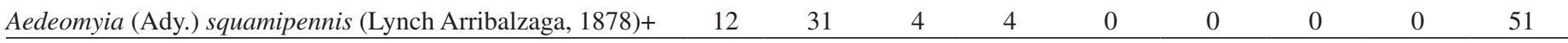

Tribe Aedini

Aedes (How.) fulvithorax (Lutz, 1904)+

Ae. (Och.) fulvus (Wiedemann, 1828)

Ae. (Och.) hastatus Dyar 1922*+

Ae. (Och.) scapularis (Rondani 1848)

Ae. (Och.) serratus (Theobald 1901)

Ae. (Och.) stigmaticus (Edwards 1922)*+

Ae. (Och.) taeniorhynchus (Wiedemann 1821)

Ae. (Stg.) aegypti (Linnaeus 1762)

Haemagogus (Con.) leucocelaenus (Dyar \& Shannon, 1924)+

Hg. (Hag.) janthinomys Dyar, 1921+

Hg. (Hag.) spegazzinii Brethés, 1912

Psorophora (Gra.) cingulata Fabricius, 1805

Ps. (Jan.) albigenu (Peryassu, 1908)*+

Ps. (Jan.) discrucians (Walker, 1856)*+

0

\begin{tabular}{ccccccccc}
0 & 0 & 0 & 1 & 0 & 0 & 0 & 0 & 1 \\
0 & 2 & 0 & 13 & 0 & 0 & 0 & 1 & 16 \\
0 & 1 & 0 & 3 & 0 & 0 & 0 & 0 & 4 \\
25 & 393 & 6 & 526 & 1 & 176 & 0 & 802 & 1,929 \\
0 & 0 & 0 & 3 & 0 & 0 & 0 & 1 & 4 \\
0 & 134 & 0 & 207 & 0 & 1 & 0 & 0 & 342 \\
0 & 0 & 0 & 0 & 0 & 0 & 0 & 1 & 1 \\
0 & 1 & 0 & 0 & 0 & 0 & 0 & 0 & 1 \\
0 & 0 & 0 & 2 & 0 & 0 & 0 & 0 & 2 \\
0 & 2 & 0 & 2 & 0 & 0 & 0 & 0 & 4 \\
0 & 2 & 0 & 0 & 0 & 0 & 0 & 2 & 4 \\
0 & 0 & 0 & 0 & 0 & 0 & 0 & 2 & 2 \\
0 & 7 & 0 & 30 & 0 & 0 & 0 & 0 & 37 \\
0 & 30 & 0 & 557 & 0 & 0 & 0 & 9 & 596 \\
0 & 6 & 0 & 63 & 0 & 0 & 0 & 3 & 72 \\
\hline
\end{tabular}

Ps. (Jan.) ferox (Von Humboldt, 1819)

Tribe Culicini

Culex (Cux.) ameliae Casal, 1967*+

Cx. (Cux.) bidens Dyar, 1922*+

Cx. (Cux.) habilitator Dyar \& Knab, 1906*+

Cx. (Cux.) restuans Theobald, 1901*+

Cx. (Cux.) salinarius Coquillett, 1904*+

Cx. (Cux.) saltanensis Dyar, 1928*+

Cx. (Cux.) scimitar Branch \& Seabrook, 1959*+

$C x$. (Mel.) complexo Vomerifer

Cx. (Mel.) group Atratus

Cx. (Mel.) section Melanoconion

Tribe Mansoniini

Coquillettidia (Rhy.) albicosta (Peryassú, 1908)+

Cq. (Rhy.) hermanoi (Lane \& Coutinho, 1940)*+

Cq. (Rhy.) juxtamansonia (Chagas, 1907)

Cq. (Rhy.) lynchi Shannon 1931*+

\begin{tabular}{ccccccccc}
1 & 0 & 0 & 0 & 0 & 0 & 0 & 0 & 1 \\
0 & 0 & 0 & 1 & 0 & 0 & 0 & 0 & 1 \\
0 & 1 & 0 & 0 & 0 & 0 & 0 & 0 & 1 \\
0 & 1 & 0 & 0 & 0 & 0 & 0 & 1 & 2 \\
0 & 0 & 0 & 0 & 0 & 0 & 0 & 1 & 1 \\
0 & 0 & 0 & 0 & 0 & 1 & 0 & 0 & 1 \\
0 & 1 & 0 & 2 & 0 & 0 & 0 & 0 & 3 \\
2 & 0 & 0 & 0 & 0 & 0 & 0 & 0 & 2 \\
1 & 0 & 0 & 0 & 0 & 0 & 0 & 0 & 1 \\
0 & 0 & 0 & 0 & 0 & 0 & 7 & 0 & 7 \\
\hline & & & & & & & & \\
0 & 10 & 1 & 181 & 0 & 0 & 0 & 0 & 192 \\
0 & 0 & 0 & 1 & 0 & 0 & 0 & 0 & 1 \\
0 & 0 & 0 & 0 & 0 & 2 & 0 & 0 & 2 \\
\hline
\end{tabular}


SANTOS, C.F.; SILVA, A.C.; RODRIGUES, R.A.; JESUS, J.S.R. \& BORGES, M.A.Z. - Inventory of mosquitoes (Diptera: Culicidae) in conservation units in Brazilian tropical dry forests. Rev. Inst. Med. Trop. Sao Paulo, 57(3): 227-32, 2015.

Table 1

Culicidae species sampled in the dry and wet seasons in the period between August 2008 and July 2012 in Mata Seca State Park (MSSP), Lagoa do Cajueiro State Park (LCSP), Jaiba Biological Reserve (JBR) and Serra Azul Biological Reserve (SABR), in the northern region of the state of Minas Gerais, Brazil (cont.)

\begin{tabular}{|c|c|c|c|c|c|c|c|c|c|}
\hline \multirow{2}{*}{ SPECIES } & \multicolumn{2}{|c|}{ MSSP } & \multicolumn{2}{|c|}{ LCSP } & \multicolumn{2}{|c|}{ JBR } & \multicolumn{2}{|c|}{ SABR } & \multirow{2}{*}{ Total } \\
\hline & Dry & Wet & Dry & Wet & Dry & Wet & Dry & Wet & \\
\hline Cq. (Rhy.) nigricans (Coquillett, 1904) & 7 & 810 & 0 & 38 & 0 & 0 & 0 & 0 & 855 \\
\hline Cq. (Rhy.) venezuelensis (Theobald, 1912) & 9 & 598 & 0 & 116 & 0 & 0 & 0 & 1 & 724 \\
\hline Mansonia (Man.) humeralis Dyar \& Knab 1916+ & 65 & 400 & 228 & 510 & 0 & 2 & 0 & 1 & 1,206 \\
\hline Ma. (Man.) indubitans Dyar \& Shannon 1925+ & 3 & 26 & 730 & 113 & 0 & 1 & 0 & 2 & 875 \\
\hline Ma. (Man.) pseudotitillans (Theobald, 1901)+ & 24 & 401 & 0 & 9 & 0 & 0 & 0 & 0 & 434 \\
\hline Ma. (Man.) titillans (Walker, 1848) & 161 & 1,352 & 508 & 1,010 & 3 & 0 & 0 & 6 & 3,040 \\
\hline
\end{tabular}

Tribe Uranotaeniini

Uranotaenia (Ura.) geometrica Theobald, 1901

Ur. (Ura.) lowii Theobald 1901*+

Ur. (Ura.) pulcherrima Lynch Arribalzaga $1891 *+$

Tribe Sabethini

\begin{tabular}{|c|c|c|c|c|c|c|c|c|c|}
\hline Limatus paraensis (Theobald 1903) & 0 & 0 & 0 & 17 & 0 & 0 & 0 & 0 & 17 \\
\hline Sabethes (Pey.) undosus (Coquillett, 1906)+ & 0 & 1 & 0 & 0 & 0 & 0 & 0 & 0 & 1 \\
\hline Total & 444 & 4,693 & 1,589 & 3,459 & 6 & 185 & 8 & 835 & 11,219 \\
\hline
\end{tabular}

* New record to the Minas Gerais State. + new record to the semi-arid region of Minas Gerais.

\section{DISCUSSION}

Of all the collected specimens, 8,170 (73\%) were characterized by their use of permanent breeding habitats (e.g. ponds, marshes, river backwaters and puddles) for their larval and pupal (immature) stages; these individuals represented Anophelinae subfamily and Mansoniini, Aedomyiini tribes and, in some cases, Culicini. The remaining 27\% (3,040 specimens) were characterized by their use of temporary breeding habitats (e.g., puddles, hollow bamboo, bromeliads and other phytotelmata) in their larval and pupal stages, representing primarily Aedini, Uranotaeniini and Sabethini tribes.

Mosquito species belonging to the Mansoniini tribe were the most abundant $(68.3 \%$ ), of which the species Mansonia titillans alone accounted for $27.10 \%$ of all mosquitoes sampled in the study. Mosquitoes of the Aedini tribe were the second most abundant group of all mosquitoes collected (26.87\%), with Aedes scapularis as the dominant species within the tribe (17.19\%). Among the Anopheles species collected, Anopheles darlingi was the most abundant and amounted to $1.36 \%$ of all mosquitoes sampled.

The large percentage of mosquito species using permanent reservoirs might be related to the relatively long dry periods, which are characteristic of the study area. Prolonged droughts can have a damaging effect on the viability of Aedini mosquitoes' eggs ${ }^{24}$ and can negatively affect the nutritional quality of the detritus found in temporary breeding habitats ${ }^{4}$. Despite the long dry periods, the community of mosquitoes manages to survive, mainly using the vegetation surrounding the ponds located in PEMS and PELC.

The large abundance of mosquitoes within the Mansoniini tribe can be explained by the influence of ponds located on the banks of the São Francisco River, located in the MSSP and LCSP. Even in dry seasons, these ponds act as major breeding grounds for Mansoniini mosquitoes in the larval and pupal stages as they contain lots of aquatic vegetation, the aerenchyma of the roots providing the mosquitoes with oxygen ${ }^{10}$. Some Mansoniini mosquitoes, such as Coquillettidia venezuelensis, are involved in the transmission of arboviruses, such as Eastern equine encephalitis virus (actual vectors) and Oropouche virus (potential vectors $)^{10}$. In addition, Ma. titillans have been found to be naturally infected with the Venezuelan equine encephalitis virus. Thus, the large abundance of mosquitoes of the genus Mansonia in the conservation units sampled could potentially impact wild bird conservation, as these mosquitoes are ornithophilic and can transmit avian malaria ${ }^{14,26}$.

The high abundance of Aedes scapularis was probably related to the vegetational structure of the study area, which is in the process of natural regeneration from successive anthropogenic pressures, such as agriculture and livestock farming ${ }^{17}$. These environments provide ideal conditions for the establishment of Ae. scapularis populations, as these mosquitoes have a marked tendency to invade artificially modified environments $^{8,11,12}$. Furthermore, the larval and pupal stages of Ae. scapularis develop in temporary ground pools formed by rainfall, and are comparable to those known to exist in environments in the initial stages of natural regeneration ${ }^{5,10}$.

At least 15 viruses have been isolated from Ae. scapularis, including the Rocio virus, Yellow fever virus, and Venezuelan equine encephalitis virus; this species may also be a vector of Bancroftian filariasis ${ }^{18,20}$. VASCONCELOS et al. ${ }^{27}$ isolated a strain of Yellow fever virus from field-captured Ae. scapularis. Previously, only experimental laboratory infections had been reported in this species. Considering the ecological and epidemiological characteristics reported for this species, these mosquitoes can be a potential bridge between wild arboviruses and human populations in this region, given the current state of anthropogenic modifications of the study region. 
SANTOS, C.F.; SILVA, A.C.; RODRIGUES, R.A.; JESUS, J.S.R. \& BORGES, M.A.Z. - Inventory of mosquitoes (Diptera: Culicidae) in conservation units in Brazilian tropical dry forests. Rev. Inst. Med. Trop. Sao Paulo, 57(3): 227-32, 2015.

Mosquitoes of the Psorophora genus were the most abundant Aedini after Ae. scapularis; this might be explained by the fact that these types of mosquitoes share the same breeding habitats ${ }^{3,19,25}$. Although Psorophora have been found to carry some types of infection in nature, mosquitoes of this genus are not considered epidemiologically significant vectors. These mosquitoes are, however, treated as potential incidental vectors of disease due to some of their behavioral characteristics, such as eclecticism in the choice of blood host and exophilic behavior ${ }^{10}$.

The abundance of An. darlingi recorded deserves particular attention, as this species is the main vector of malaria parasites in Brazil and is widely distributed across South America ${ }^{23}$; additionally, these mosquitoes have an increased capacity for taking blood meals within and around residential regions ${ }^{6}$. Although Anopheles argyritarsis and Anopheles triannulatus are not the primary vectors of the Plasmodium species responsible for malaria, these species are of great epidemiological interest because of their high abundance and anthropophilic nature ${ }^{6}$.

The abundance of new Culicid records for Minas Gerais State, and for the semi-arid region of the state, indicates that studies of mosquito communities in forest remnants are still required, especially with regards to the development and maintenance of support programs aimed at the prevention of disease transmission to humans and other animals.

\section{RESUMO}

\section{Inventário de mosquitos (Diptera: Culicidae) em unidades de conservação em florestas tropicais secas brasileiras}

No Brasil, a maior parte dos estudos relacionados à família Culicidae se concentram em regiões de florestas úmidas, existindo uma lacuna no conhecimento da diversidade destes mosquitos em regiões com características climáticas e vegetacionais diferentes. $\mathrm{O}$ objetivo desse trabalho foi inventariar a fauna de culicídeos em unidades de conservação do semi-árido de Minas Gerais, visando assim contribuir para o conhecimento da diversidade de Culicidae desta região. O estudo foi realizado em quatro unidades de conservação localizadas na região norte do estado de Minas Gerais, Brasil, área representada por fragmentos de Floresta Tropical Seca (FTS). Foram utilizados três métodos de coleta: armadilha do tipo Shannon, armadilha luminosa do tipo CDC e coleta ativa. Durante o período de agosto de 2008 a julho de 2012 foi coletado um total de 11.219 espécimes de mosquitos, distribuídos em 11 gêneros e 45 espécies. Foram registrados 15 novos registros de mosquitos para o estado de Minas Gerais e 26 novos registros para a região do semi-árido de Minas Gerais. O elevado número de novos registros de Culicidae na região demonstra a importância de estudos de inventário para o aumento do conhecimento da biodiversidade de culicídeos em Minas Gerais, e em particular a região do semi-árido do estado.

\section{ACKNOWLEDGEMENTS}

The authors gratefully acknowledge the staff of the Instituto Estadual de Florestas (IEF-MG), for allowing them to work and stay at Mata Seca State Park (MSSP), Lagoa do Cajueiro State Park (LCSP), Jaiba Biological Reserve (JBR) and Serra Azul Biological Reserve (SABR) for logistical support. This work was carried out with the aid of a grant from Conselho Nacional de Desenvolvimento Científico e Tecnológico
(CNPq -563304/2010-3 and 562955/2010-0), Fundação de Amparo à Pesquisa de Minas Gerais (FAPEMIG CRA - APQ-00001-11) and the Inter-American Institute for Global Change Research (IAI-CRN II-021).

\section{REFERENCES}

1. Andrade RM, Leal JM. Distribuição de anofelinos na bacia hidrográfica do rio São Francisco. Estados de Minas Gerais, Bahia, Goiás, Pernambuco, Alagoas e Sergipe. Rev Bras Malar D Trop. 1960;1:147-63.

2. Antunes FZ. Caracterização climática: caatinga do estado de Minas Gerais. Inf Agropecuário Belo Horizonte. 1994;17:15-9.

3. Arnell JH. Mosquito studies (Diptera, Culicidae). XXXIII. A revision of the Scapularis group of Aedes (Ochlerotatus). Contrib Am Entomol Inst (Ann Arbor). 1976;13:1-144

4. Aspbury AS, Juliano SA. Negative effects of habitat drying and prior exploitation on the detritus resource in an ephemeral aquatic habitat. Oecologia. 1998;115:137-48.

5. Casanova C, Prado AP. Key-factor analysis of immature stages of Aedes scapularis (Diptera: Culicidae) populations in southeastern Brazil. Bull Entomol Res. 2002;92:271-7.

6. Consoli RAGB, Oliveira RL. Principais mosquitos de importância sanitária no Brasil. Rio de Janeiro: Ed. Fiocruz; 1994

7. Deane LM. Malaria vectors in Brasil. Mem Inst Oswaldo Cruz. 1986;81(Suppl 2):514.

8. Dorvillé LFM. Mosquitoes as bioindicators of forest degradation in southeastern Brazil, a statistical evaluation of published data in the literature. Stud Neotrop Fauna Environm. 1996;31:68-78

9. Faran ME. Mosquito studies (Diptera, Culicidae) XXXIV. A revision of the Albimanus Section of the subgenus Nyssorhynchus of Anopheles. Contrib Am Entomol Inst (Ann Arbor). 1980;15:1-214.

10. Forattini OP. Culicidologia médica. São Paulo: EDUSP; 2002

11. Forattini OP, Alves AC, Natal D, Santos JLF. Observações sobre atividades de mosquitos Culicidae em mata primitiva da encosta no Vale do Ribeira São Paulo, Brasil. Rev Saúde Pública. 1986;20:1-20.

12. Forattini OP, Kakitani I, Massad E, Marucci D. Studies on mosquitoes (Diptera: Culicidae) and anthropic environment. 9. Synanthropy and epidemiological vector role of Aedes scapularis in South-Eastern Brazil. Rev Saúde Pública. 1995;29:199207.

13. Gama RA, Andrade AJ, Andrade MR, Resende MC, Eiras, AE. Avaliação da armadilha HP iscada com diferentes taxas de liberação de octenol na captura de anofelinos (Diptera: Culicidae) em Brejo do Mutambal, Município de Varzelândia, Estado de Minas Gerais. Rev Soc Bras Med Trop. 2007;40:408-10.

14. Lacorte GA, Félix GMF, Pinheiro RRB, Chaves AV, Almeida-Neto G, Neves FS, et al. Exploring the diversity and distribution of neotropical avian malaria parasites: a molecular survey from southeast Brazil. PLOS One. 2013;8:1-9.

15. Lane J. Neotropical Culicidae. Tribe Culicini, Deinocerites, Uranotaenia, Mansonia, Orthopodomyia, Aedomyia, Aedes, Psorophora, Haemagogus, tribe Sabethini, Trichoprosopon, Wyeomyia, Phoniomyia, Limatus and Sabethes. São Paulo: Universidade de São Paulo; 1953. v. 2

16. Maciel CS. Lista de culicineos do Estado de Minas Gerais, Brasil (Diptera, Culicidae). Rev Bras Malar D Trop. 1962;14:465-94.

17. Madeira GB, Espirito-Santo MM, Neto SA, Nunes YRF, Sánches-Azofeifa GA, Fernandes GW, et al. Changes in tree and liana communities along a succecional gradient in a tropical dry forest in south-eastern Brazil. Plant Ecol. 2009;201:291-304. 
SANTOS, C.F.; SILVA, A.C.; RODRIGUES, R.A.; JESUS, J.S.R. \& BORGES, M.A.Z. - Inventory of mosquitoes (Diptera: Culicidae) in conservation units in Brazilian tropical dry forests. Rev. Inst. Med. Trop. Sao Paulo, 57(3): 227-32, 2015.

18. Mitchell CJ, Forattini OP. Experimental transmission of Rocio encephalitis virus by Aedes scapularis (Diptera: Culicidae) from the epidemic zone in Brazil. J Med Entomol. 1984;21:34-7.

19. Piovezan R, Azevedo TS, Von Zuben CJ. Spatial evaluation of larvae of Culicidae (Diptera) from different breeding sites: application of a geospatial method and implications for vector control. Rev Bras Entomol. 2012;56:368-76.

20. Rachou RG, Lima MM, Neto JAF, Martins CM. Inquérito epidemiológico de filariose bancroftiana em uma localidade de Santa Catarina, como fase preliminar de uma prova profilática. Constatação de transmissão extradomiciliária por um novo vetor, Aedes scapularis. Rev Bras Malar D Trop. 1955;7:51-70.

21. Rueda LM. Global diversity of mosquitoes (Insecta: Diptera: Culicidae) in freshwater. Hydrobiologia. 2008;595:477-87.

22. Sanches-Azofeifa GA, Quesada M, Rodriguez JP, Nassar JM, Stoner KE, Castillo A, et al. Research priorities for neotropical dry forests. Biotropica. 2005;37:477-85.

23. Sinka ME, Bangs MJ, Manguin S, Rubio-Palis Y, Chareonviriyaphap T, Coetzee M, et al. A global map dominant malaria vectors. Parasit Vectors. 2012;5:69.
24. Sota T, Mogi M. Interspecific variation in desiccation survival time of Aedes (Stegomyia) mosquito eggs is correlated with habitat and egg size. Oecologia. 1992;90:353-8.

25. Stein M, Ludueña-Almeida F, Willener JA, Almirón WR. Classification of immature mosquito species according to characteristics of the larval habitat in the subtropical province of Chaco, Argentina. Mem Inst Oswaldo Cruz. 2011;106:400-7.

26. Valkiūnas G. Avian malaria parasites and other haemosporidia. Boca Raton: CRC Press; 2005.

27. Vasconcelos PC, Costa ZG, Travassos da Rosa ES, Luna E, Rodrigues SG, Barros VLRS, et al. Epidemic of jungle yellow fever in Brazil, 2000: implications of climatic alterations in disease spread. J Med Virol. 2001;65:598-604.

Received: 20 December 2013

Accepted: 4 September 2014 